\title{
Impact of Cyclic Densification on Bending Strength and Modulus of Elasticity of Wood from Temperate and Tropical Zones
}

\begin{abstract}
Agnieszka Laskowska *
Oak (Quercus robur L.), iroko (Milicia excelsa (Welw.) C.C. Berg), and tauari (Couratari spp.) wood were subjected to cyclic thermo-mechanical treatment (CTMT). The densification temperature amounted to $100{ }^{\circ} \mathrm{C}$ or $150{ }^{\circ} \mathrm{C}$. The greatest changes in the modulus of rupture (MOR) value of the iroko wood, depending on the number of thermo-mechanical modification cycles, were noted. The MOR of the iroko wood, densified at $100^{\circ} \mathrm{C}$ or $150^{\circ} \mathrm{C}$, after second thermo-mechanical modification cycle was twice as high as before the modification. No significant differences were observed between the modulus of elasticity (MOE) of oak wood before and after one modification cycle. Similar dependencies were noted in iroko wood. The thermo-mechanical modification performed over two cycles led to the highest increase, by about $56 \%$, in MOE in oak wood densified at $150^{\circ} \mathrm{C}$. It was demonstrated that modification at 150 ${ }^{\circ} \mathrm{C}$ had a negative impact on iroko wood, which was manifested in the lower compression ratio of iroko at $150^{\circ} \mathrm{C}$ than at $100^{\circ} \mathrm{C}$.
\end{abstract}

Keywords: European oak; Densification; Iroko; Tauari; Thermo-mechanical modification

Contact information: The Institute of Wood Sciences and Furniture, Faculty of Wood Technology, Warsaw University of Life Sciences - SGGW, 159 Nowoursynowska St., 02-776 Warsaw, Poland;

*Corresponding author: agnieszka_laskowska@sggw.pl

\section{INTRODUCTION}

Wood can be subjected to various kinds of modification. One method of improving its physical and mechanical properties is through densification. Ülker et al. (2012) distinguished three densification methods: thermo-mechanical, thermo-hydro-mechanical, and viscoelastic thermally compression. The mechanical properties of wood are correlated with its physical properties. For this reason, increasing the wood's density by densification enhances its mechanical properties. Moreover, no chemicals are introduced into the wood's structure in the course of such modification, which is undoubtedly an advantage of this form of treatment.

Thermo-mechanical (TM) modification is a process involving compression by pressing heated wood. It is usually completed in a hydraulic press with heated plates (Kurowska et al. 2010; Laine et al. 2013; Bekhta et al. 2014a,b; Laine et al. 2016). Methods of continuous wood densification using rolls have also been developed (Gaff and Gašparík 2015). The technological process is usually divided into three stages. In addition to pressing, the wood is subjected to pre-treatment and final treatment. The purpose of pretreatment is to plasticize the wood's structural components to facilitate the densification process (Fu et al. 2016). The final treatment aims to reduce post-densification internal strain to prevent deformations (Rautkari et al. 2013; Popescu et al. 2014; Zhan and Avramidis 2016). The TM modification is usually carried out in the temperature range 100 to $200{ }^{\circ} \mathrm{C}$. The pressing pressure depends on many factors: kind of densification (surface, 
volume), press type, wood species, wood moisture content, and sample thickness or assumed compression ratio (Rautkari et al. 2011; Ülker et al. 2012; Laskowska 2017). Therefore, the pressing pressure is in a very wide range from $1 \mathrm{MPa}$ to $100 \mathrm{MPa}$. Densification is applied to both low- and high-density wood (Rautkari et al. 2010; Kutnar and Kamke 2012; Tu et al. 2014; Gašparík et al. 2016; Zhan and Avramidis 2016). Research has involved wood from different climatic zones. Tropical zone wood is characterized by a more complex anatomical and chemical structure than wood from the temperate zone. A typical feature of many wood species from the tropical zone is their irregular arrangement of fibres, which has a significant negative impact on the wood's mechanical properties. Moreover, tropical zone wood possesses more parenchyma (Richter and Dallwitz 2000; Wagenführ 2007), which may likewise significantly affect the course of TM modification.

The properties of densified wood are determined by a number of factors, among which the temperature of treatment is the most significant (Dilik and Hiziroglu 2012; Fang et al. 2012; Ülker et al. 2012; Laskowska 2017; Ülker and Hiziroglu 2017). Such dependence results from the fact that wood's structural components have different softening temperatures, which in turn largely depend on wood moisture content (Kutnar and Šernek 2007; Ülker et al. 2012). Another significant factor in the technological factors' group is the pressing pressure, which determines the wood's compression ratio, and consequently its density and the correlated mechanical properties (Gašparík et al. 2016). In the group of material-related factors, the wood's bending strength is principally affected by the anatomical structure, density, earlywood and latewood proportion, moisture content, wood's temperature, type and distribution of knots, and other defects (irregular fibres) or damage (Blomberg et al. 2005; Kretschmann 2010).

Several publications have researched the impact of technological parameters of thermo-mechanical modification, chiefly on the physical properties of wood. The most frequently described wood properties are set recovery, density profile, and surface properties (Kutnar et al. 2009; Candan et al. 2010; Rautkari et al. 2010; İmirzi et al. 2014; Laine et al. 2016). Among the mechanical properties of thermo-mechanically modified wood, the most frequently analysed is hardness (Fu et al. 2016; Gašparík et al. 2016; Laine et al. 2016). Data on the bending strength and the modulus of elasticity of thermomechanically modified wood are scarce. Because bending strength is a major factor in the work of such building elements as floors or beams, it is important to analyse these issues. Thermo-mechanical modification is dedicated to such materials.

Cyclic thermo-mechanical treatment (CTMT) is an innovative solution developed to improve the properties of wood to a higher degree than that achieved by 'standard' thermo-mechanical modification (Laskowska et al. 2018). Consequently, the main objective of this study was to determine the impact of CTMT on the modulus of rupture (MOR) and the modulus of elasticity (MOE) of wood species from the temperate climate zone (oak) and tropical zone (iroko, tauari). The wood species selected for research are widely used in manufacturing floors, furniture, and interior furnishings. The following issues were subject to analysis: significance and degree of impact of technological factors (densification temperature, number of treatment cycles) and material-related factors (wood species) on the thickness, density, MOR, and MOE of wood. Interrelations were determined between these factors and the tested wood properties. 


\section{EXPERIMENTAL}

\section{Materials}

The wood samples used in the tests were made of European oak (Quercus robur L.), iroko (Milicia exelsa (Welw.) C.C. Berg), and tauari (Couratari spp.). Their dimensions were: $130 \mathrm{~mm}$ (longitudinal), $80 \mathrm{~mm}$ (tangential), and $8.50 \mathrm{~mm}$ (radial). Each variant of thermo-mechanical modification was tested on 20 samples. The European oak wood was obtained from central Poland, iroko wood from Nigeria, and tauari wood from Brazil. The surface of the wood samples was finished by planing. After the samples had been brought to an air-dry condition in normal climate (temperature $20{ }^{\circ} \mathrm{C} \pm 2{ }^{\circ} \mathrm{C}$, relative humidity $65 \% \pm 5 \%$ ), the wood moisture content was determined in accordance with ISO 13061-1 (2014). The moisture content of wood amounted to $7.92 \%( \pm 0.68 \%)$. The wood density was determined using the stereometric method in accordance with the requirements of ISO 13061-2 (2014).

Table 1. Data on the Wood Species Tested

\begin{tabular}{|c|c|c|c|c|}
\hline Latin Name & $\begin{array}{c}\text { English Trade } \\
\text { Name of Wood } \\
\text { (and Code) } \\
\text { According to } \\
\text { EN-13556 } \\
(2003)\end{array}$ & Origin & $\begin{array}{c}\text { Structure of } \\
\text { Wood }\end{array}$ & Wood Anatomical Features \\
\hline Couratari spp. & Tauari (CIXX) & $\begin{array}{c}\text { South } \\
\text { America }\end{array}$ & $\begin{array}{c}\text { Deciduous } \\
\text { diffuse- } \\
\text { porous }\end{array}$ & $\begin{array}{c}\text { Axial parenchyma banded, } \\
\text { apotracheal axial parenchyma } \\
\text { diffuse-in-aggregates } \\
\text { (in short, wavy lines), } \\
\text { paratracheal axial parenchyma } \\
\text { scanty }\end{array}$ \\
\hline $\begin{array}{c}\text { Milicia excelsa } \\
\text { (Welw.) C.C. } \\
\text { Berg }\end{array}$ & Iroko (MIXX) & Africa & $\begin{array}{c}\text { Deciduous } \\
\text { diffuse- } \\
\text { porous }\end{array}$ & $\begin{array}{c}\text { Irregular fibres arrangement, } \\
\text { axial parenchyma banded, } \\
\text { paratracheal axial parenchyma } \\
\text { vasicentric, aliform, and } \\
\text { confluent }\end{array}$ \\
\hline $\begin{array}{c}\text { Quercus robur L. } \\
\text { European oak } \\
\text { (QCXE) }\end{array}$ & Europe & $\begin{array}{c}\text { Deciduous } \\
\text { ring-porous }\end{array}$ & \begin{tabular}{c} 
Broad rays \\
\hline
\end{tabular} \\
\hline
\end{tabular}

\section{Methods}

Cyclic thermo-mechanical treatment

Oak, iroko, and tauari wood were subjected to CTMT. One treatment cycle consisted of three stages: i) heating the wood in a hydraulic press (platens dimension 650 $\mathrm{mm} \times 650 \mathrm{~mm}$, maximum manometric pressure $25 \mathrm{MPa}$ ) in laboratory conditions; ii) wood densification; and iii) cooling the wood samples in an unheated hydraulic press without exerting pressure. The thermo-mechanical modification was completed in one or in two cycles. Both the heating time and wood densification time amounted to $120 \mathrm{~s}$, whereas the time of cooling the wood in a hydraulic press was $240 \mathrm{~s}$. The treatment temperature amounted to $100{ }^{\circ} \mathrm{C}$ or $150{ }^{\circ} \mathrm{C}$, and the unit pressure to $45 \mathrm{~N} / \mathrm{mm}^{2}$. The cooling took place in a normal climate (temperature $20{ }^{\circ} \mathrm{C} \pm 2{ }^{\circ} \mathrm{C}$, relative humidity $65 \% \pm 5 \%$ ). After the treatment, the wood samples were conditioned in a normal climate for 7 days. 


\section{Measurement methods}

The wood samples were prepared in accordance with ISO 3129 (2012). The compression ratio (CR) was calculated according to Eq. 1 , where $t_{\mathrm{o}}$ is the original thickness $(\mathrm{mm})$ and $t_{\mathrm{d}}$ is the thickness of wood after densification $(\mathrm{mm})$ :

$$
C R(\%)=\frac{t_{\mathrm{o}}-t_{\mathrm{d}}}{t_{\mathrm{o}}}
$$

The wood's MOR and MOE tests were conducted in accordance with the methodology specified in the ISO 13061-3 (2014) and ISO 13061-4 (2014) standards, with minor alterations. They resulted from the size of the wood samples used for thermomechanical modification. The samples used for testing the MOR and MOE of wood were $130 \mathrm{~mm}$ long and $10 \mathrm{~mm}$ wide. The thickness of the control samples was $8.66 \mathrm{~mm}( \pm 0.12$ $\mathrm{mm}$ ) and that of the modified samples corresponded to the thickness of samples after modification. In accordance with the requirements of the ISO 13061-3 (2014) and ISO 13061-4 (2014) standards, the support spacing depended on the thickness of samples and equalled twelve times the sample thickness. The MOR and MOE research was carried out using a computer program coupled with an Instron ${ }^{\circledR}$ testing machine, model 3369 (Instron ${ }^{\circledR}$, Norwood, MA, USA). The wood properties were determined for 20 control samples and for each variant of thermo-mechanical modification of oak, iroko, and tauari.

\section{Statistical analysis}

Statistical analyses were performed using STATISTICA (version 12) software from StatSoft, Inc. (Tulsa, OK, USA). The statistical analysis of the results was performed at a significance level of 0.05 .

\section{RESULTS AND DISCUSSION}

A detailed analysis (based on analysis of variance (ANOVA), Fischer's F-test) of the significance and degree of impact of temperature and number of thermo-mechanical modification cycles on thickness, density, MOR, and MOE, depending on the species of wood modified, are presented in Table 2. The impact of modification temperature on the properties of densified wood was greatest in tauari wood, ranging from $39 \%$ to $57 \%$ depending on the wood property tested, whereas the smallest impact of temperature was observed in densified iroko wood. The modification temperature affected the thickness and density of densified iroko wood by $38 \%$ and $28 \%$, respectively, but it had no significant impact on MOR or MOE. The number of thermo-mechanical modification cycles had the greatest impact on the mechanical properties of iroko wood, and the smallest on the tauari wood. The impact of the number of cycles on MOR and MOE of iroko wood amounted to $78 \%$ and $61 \%$, respectively, and $6 \%$ and $11 \%$ for the MOR and MOE of tauari wood, respectively. For oak wood, the number of cycles was responsible for $33 \%$ and $72 \%$ changes, respectively, of MOR and MOE variation. The impact of the number of thermomechanical modification cycles on wood thickness and density was greatest in oak, $65 \%$ and $61 \%$, respectively. The number of cycles had a comparable impact, ranging from $25 \%$ to $37 \%$, on the thickness and density of iroko and tauari wood, respectively. A significant impact of the interaction between temperature and number of modification cycles on the thickness and density of oak and iroko wood (impact of 18 to 26\%) was also observed. 
Table 2. Statistical Evaluation of the Factors Influencing the Parameters of Oak, Iroko, and Tauari Wood

\begin{tabular}{|c|c|c|c|c|c|c|c|}
\hline \multirow{4}{*}{$\begin{array}{c}\text { Wood } \\
\text { Species }\end{array}$} & \multirow{4}{*}{ Factor } & \multicolumn{6}{|c|}{ Properties } \\
\hline & & \multicolumn{3}{|c|}{ Thickness } & \multicolumn{3}{|c|}{ Density } \\
\hline & & $\begin{array}{c}\text { Fisher's } \\
\text { F-test }\end{array}$ & Sig. Level & $\begin{array}{c}\text { Influence } \\
\text { of Factors } \\
(\%)\end{array}$ & $\begin{array}{c}\text { Fisher's } \\
\text { F-test }\end{array}$ & Sig. Level & $\begin{array}{c}\text { Influence } \\
\text { of Factors } \\
(\%)\end{array}$ \\
\hline & & $F$ & $p$ & $X$ & $\mathrm{~F}$ & $p$ & $\mathrm{X}$ \\
\hline \multirow[t]{10}{*}{ Oak } & Temp. (1) & 21.45 & 0.000161 & 9 & 17.93 & 0.000406 & 8 \\
\hline & Cycle (2) & 158.95 & 0.000000 & 65 & 139.56 & 0.000000 & 61 \\
\hline & $(1) \times(2)$ & 42.81 & 0.000002 & 18 & 49.48 & 0.000001 & 22 \\
\hline & Error & - & - & 8 & - & - & 9 \\
\hline & & \multicolumn{3}{|c|}{ MOR } & \multicolumn{3}{|c|}{ MOE } \\
\hline & & $\mathrm{F}$ & $\mathrm{p}$ & $X$ & $\mathrm{~F}$ & $\mathrm{p}$ & $X$ \\
\hline & 1 & 19.202 & 0.000288 & 32 & 27.397 & 0.000040 & 13 \\
\hline & 2 & 19.941 & 0.000237 & 33 & 156.729 & 0.000000 & 72 \\
\hline & $1 \times 2$ & 0.949 & 0.341574 & 2 & 14.576 & 0.001077 & 7 \\
\hline & Error & - & - & 33 & - & - & 9 \\
\hline \multirow[t]{12}{*}{ Iroko } & & \multicolumn{3}{|c|}{ Thickness } & \multicolumn{3}{|c|}{ Density } \\
\hline & & $\mathrm{F}$ & $p$ & $X$ & $\mathrm{~F}$ & $p$ & $X$ \\
\hline & 1 & 93.00 & 0.000000 & 38 & 59.15 & 0.000000 & 28 \\
\hline & 2 & 72.04 & 0.000000 & 30 & 78.39 & 0.000000 & 37 \\
\hline & $1 \times 2$ & 57.53 & 0.000000 & 24 & 56.21 & 0.000000 & 26 \\
\hline & Error & - & - & 8 & - & - & 9 \\
\hline & & \multicolumn{3}{|c|}{ MOR } & \multicolumn{3}{|c|}{ MOE } \\
\hline & & $F$ & $p$ & $X$ & $\mathrm{~F}$ & $p$ & $X$ \\
\hline & 1 & 0.076 & 0.785209 & 0 & 0.819 & 0.376337 & 2 \\
\hline & 2 & 69.526 & 0.000000 & 78 & 32.817 & 0.000013 & 61 \\
\hline & $1 \times 2$ & 0.107 & 0.746563 & 0 & 0.098 & 0.758072 & 0 \\
\hline & Error & - & - & 22 & - & - & 37 \\
\hline \multirow[t]{12}{*}{ Tauari } & & \multicolumn{3}{|c|}{ Thickness } & \multicolumn{3}{|c|}{ Density } \\
\hline & & $\mathrm{F}$ & $p$ & $\mathrm{X}$ & $\mathrm{F}$ & $p$ & $X$ \\
\hline & 1 & 29.09 & 0.000028 & 39 & 44.87 & 0.000002 & 49 \\
\hline & 2 & 25.41 & 0.000063 & 34 & 23.03 & 0.000109 & 25 \\
\hline & $1 \times 2$ & 0.01 & 0.934693 & 0 & 4.11 & 0.056172 & 4 \\
\hline & Error & - & - & 27 & - & - & 22 \\
\hline & & \multicolumn{3}{|c|}{ MOR } & \multicolumn{3}{|c|}{ MOE } \\
\hline & & $\mathrm{F}$ & $\mathrm{p}$ & $X$ & $\mathrm{~F}$ & $\mathrm{p}$ & $X$ \\
\hline & 1 & 36.617 & 0.000006 & 57 & 19.801 & 0.000246 & 42 \\
\hline & 2 & 3.933 & 0.061247 & 6 & 5.149 & 0.034472 & 11 \\
\hline & $1 \times 2$ & 3.152 & 0.091068 & 5 & 2.483 & 0.130753 & 5 \\
\hline & Error & - & - & 31 & - & - & 42 \\
\hline
\end{tabular}

The results of the research showed that oak wood was the most susceptible to densification among the species tested. After the densification process, the oak wood had the smallest thickness (Fig. 1a, c), i.e., the highest compression ratio (CR). Regardless of the levels of factors tested, the CR of oak wood amounted to $c a$. $40 \%$. Iroko wood was the least susceptible to densification, with a CR of $\mathrm{ca}$. 30\%. Iroko wood has an irregular fibre arrangement, a defect that enriches the wood's figure. In contrast, this characteristic of renders its densification more difficult. The areas of irregular fibres are less susceptible to densification than those with straight fibres. Moreover, unlike oak and tauari wood, iroko possesses expanded axial parenchyma (Richter and Dallwitz 2000), which also hinders densification. It is generally assumed that wood with a lower initial density is more influenced by densification than wood with a higher initial density (Gašparík et al. 2016). 
Although it had lower density than oak and tauari, iroko wood was least susceptible to densification because of the other features mentioned. A higher modification temperature determined the thickness of iroko and tauari wood to a higher degree than that of oak wood. Moreover, it was demonstrated that a high modification temperature, at $150{ }^{\circ} \mathrm{C}$, had a negative impact on iroko wood. This was manifested in the lower compression ratio of iroko wood at $150{ }^{\circ} \mathrm{C}$ than at $100{ }^{\circ} \mathrm{C}$. The $\mathrm{CR}$ of the wood species tested was greater after the second cycle of thermo-mechanical modification than after the first cycle, and the differences were statistically significant ( $\mathrm{p}<0.05$ ). After the second cycle, the CR of tauari, oak, and iroko wood was 5, 7, and 9 percentage points higher, respectively, than after the first cycle of modification.

a)

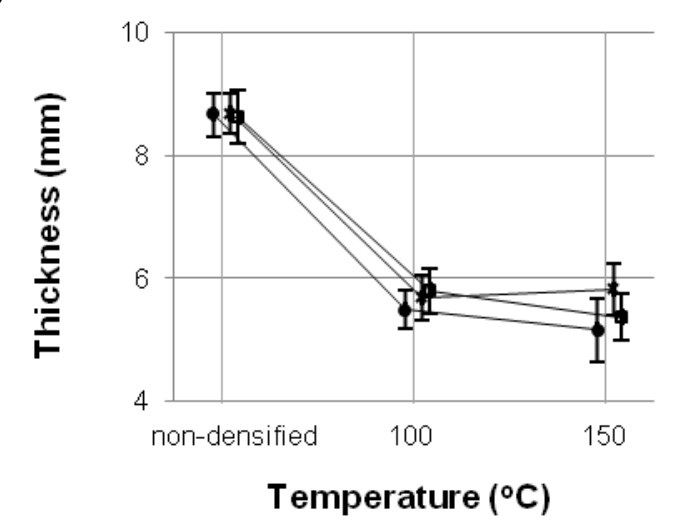

C)

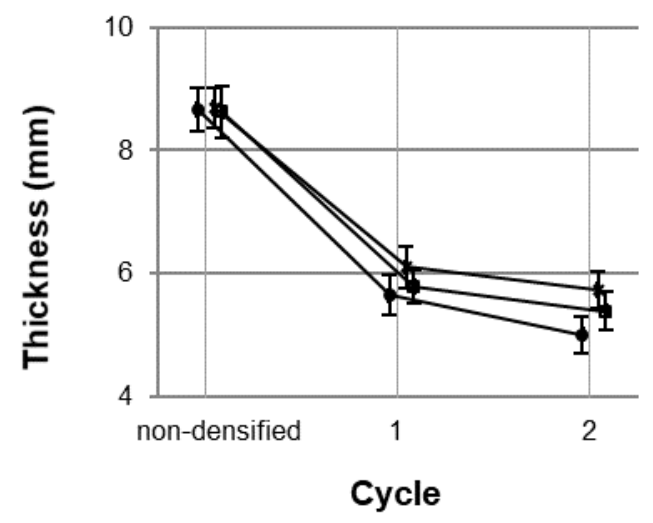

b)

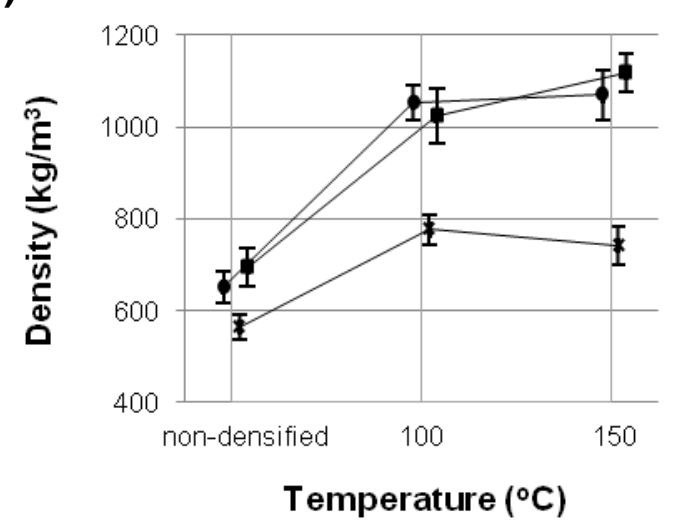

d)

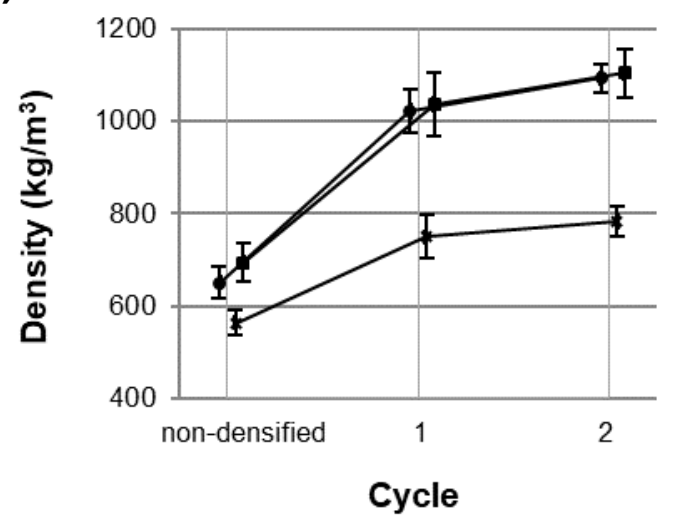

$$
\longrightarrow \text { Oak } \rightarrow \text { Iroko } \rightarrow \text { Tauari }
$$

Fig. 1. Thickness ( $a, c)$ and density (b, d) of thermo-mechanically modified wood species

The modification temperature had the greatest impact on the density of tauari wood and the smallest on the density of oak wood (Table 2). The density of tauari wood densified at $100{ }^{\circ} \mathrm{C}$ was $47 \%$ higher than that of non-densified tauari wood, whereas the tauari densified at $150{ }^{\circ} \mathrm{C}$ showed a $61 \%$ higher density than non-densified tauari wood (Fig. 1b). The density of oak wood densified at $100{ }^{\circ} \mathrm{C}$ and $150{ }^{\circ} \mathrm{C}$ was higher $62 \%$ and $64 \%$, respectively, than that of non-densified oak wood. No significant differences were observed between the density of oak wood modified at $100{ }^{\circ} \mathrm{C}$ and $150{ }^{\circ} \mathrm{C}(\mathrm{p}>0.05)$. After the second modification cycle, the density of oak wood was $6 \%$ higher than after the first 
cycle. A similar percentage of density increase was observed in tauari wood (Fig. 1d). However, the density of the tauari wood after the modification was greater. The lowest increase in density after the second cycle was observed in iroko (4\%), and the differences were statistically significant $(\mathrm{p}<0.05)$. After the first cycle, the tauari wood density amounted to $1036 \mathrm{~kg} / \mathrm{m}^{3}\left( \pm 70 \mathrm{~kg} / \mathrm{m}^{3}\right)$, whereas after the second cycle, the density was $1105 \mathrm{~kg} / \mathrm{m}^{3}\left( \pm 53 \mathrm{~kg} / \mathrm{m}^{3}\right)$. The differences were statistically significant $(\mathrm{p}<0.05)$. Laine et al. (2016) densified pine wood (Pinus sylvestris L.) at $150{ }^{\circ} \mathrm{C}$ for $1 \mathrm{~h}$. At $39 \%$ densification ratio, the authors obtained a density of $757 \mathrm{~kg} / \mathrm{m}^{3} \pm 2.6 \mathrm{~kg} / \mathrm{m}^{3}$ for the pine wood.

a)

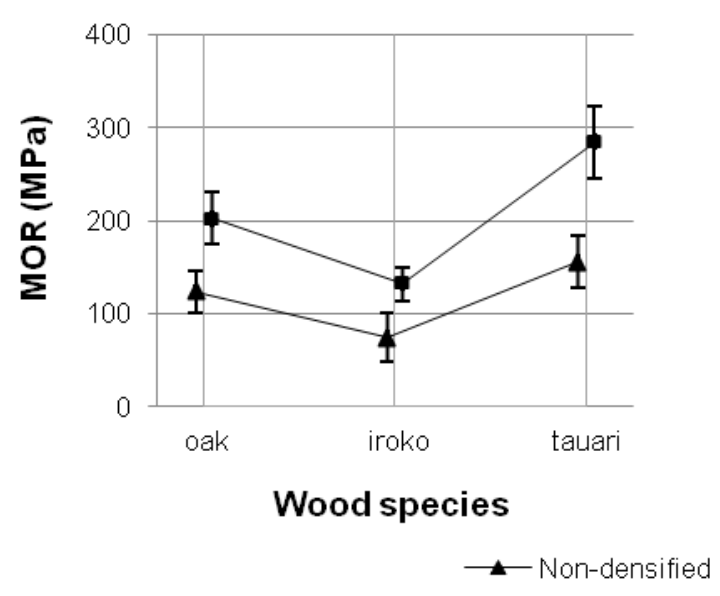

b)

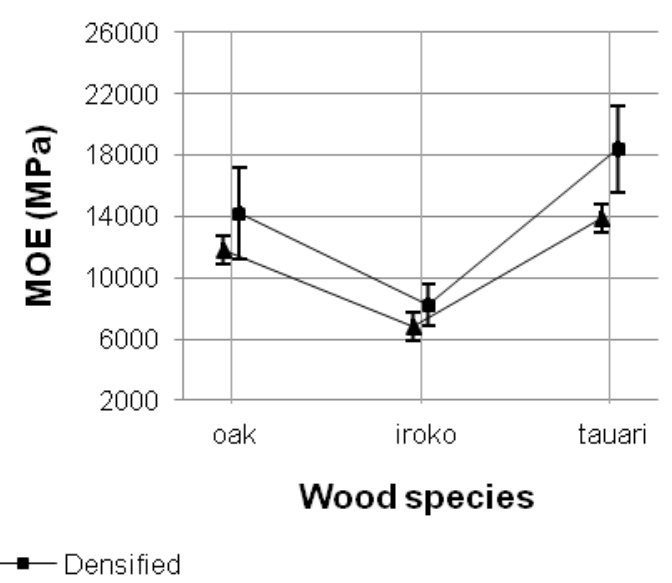

Fig. 2. MOR (a) and MOE (b) of the tested wood species

The mean MOR value for non-densified oak wood was $123 \mathrm{MPa}( \pm 22 \mathrm{MPa})$, whereas the MOR for non-densified iroko and tauari wood originating from the tropical zone amounted to $74 \mathrm{MPa}( \pm 26 \mathrm{MPa})$ and $155 \mathrm{MPa}( \pm 28 \mathrm{MPa})$, respectively (Fig. 2a). The oak and iroko MOR values were close to the data found in literature. Wagenführ (2007) stated that the MOR of oak wood ranges from $74 \mathrm{MPa}$ to $105 \mathrm{MPa}$, and the MOR of iroko ranges from $70 \mathrm{MPa}$ to $158 \mathrm{MPa}$. According to data gathered by CIRAD (2012), the mean MOR of tauari wood at a density of $620 \mathrm{~kg} / \mathrm{m}^{3}$ amounts to $87 \mathrm{MPa}( \pm 9 \mathrm{MPa})$. The higher MOR values for tauari resulted from the higher density of the wood used in the tests (694 $\mathrm{kg} / \mathrm{m}^{3} \pm 41 \mathrm{~kg} / \mathrm{m}^{3}$ ). The density of non-densified iroko wood was lower than that of oak and tauari $13 \%$ and 19\%, respectively. Moreover, iroko wood had an irregular arrangement of fibres. This natural characteristic of the species made its wood more difficult to densify. The MOR of densified oak and tauari wood were higher $64 \%$ and $84 \%$, respectively, than the MOR of these wood species before the densification. The MOR of densified iroko wood was $78 \%$ higher than before the densification. Changes to a lesser degree were observed in the wood's MOE (Fig. 2b). The MOE of oak and iroko wood was $20 \%$ higher than the MOE of these species before the densification. As a result of thermo-mechanical modification, the MOE of tauari wood was $30 \%$ higher than that of non-densified tauari wood.

The greatest changes in MOR affected by temperature were observed in tauari wood. The MOR of tauari wood modified at $100{ }^{\circ} \mathrm{C}$ exceeded the MOR of non-densified tauari wood by $65 \%$. After treatment at $150{ }^{\circ} \mathrm{C}$, the MOR of the tauari wood was twice as high as the MOR of the non-densified tauari wood. The MOR of the oak wood modified at $100{ }^{\circ} \mathrm{C}$ and $150{ }^{\circ} \mathrm{C}$ was higher than its MOR before densification $52 \%$ and $77 \%$, 
respectively. No significant differences were noted between the MOR of iroko wood modified at $100{ }^{\circ} \mathrm{C}$ and $150{ }^{\circ} \mathrm{C}$ (Fig. 3a). Similar dependences were observed by Ülker et al. (2012) in densifying Scots pine wood (Pinus sylvestris L.). The authors pointed out that the densification process increased the bending strength, but an increase in the temperature level (from $140{ }^{\circ} \mathrm{C}$ to $160{ }^{\circ} \mathrm{C}$ ) caused a decrease in bending strength.

a)

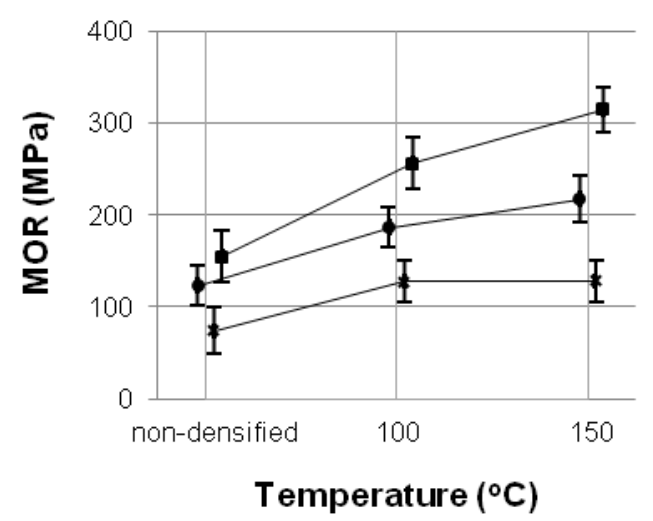

c)

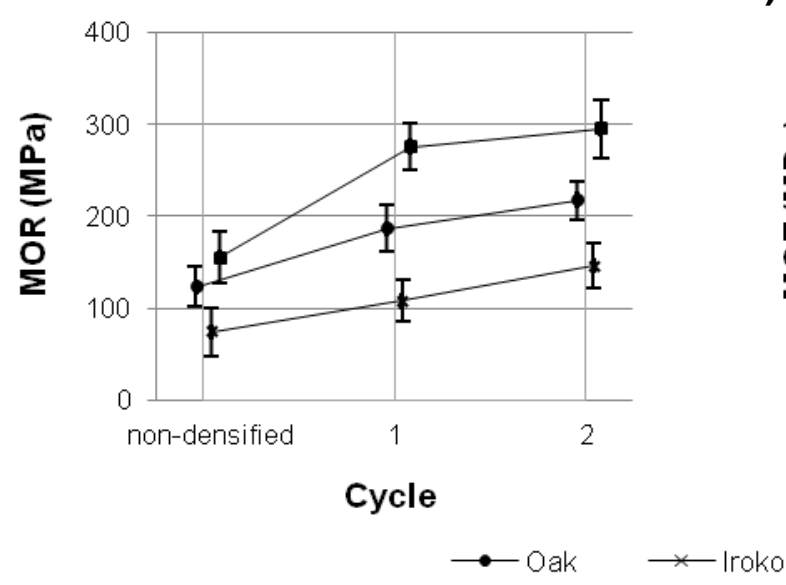

b)

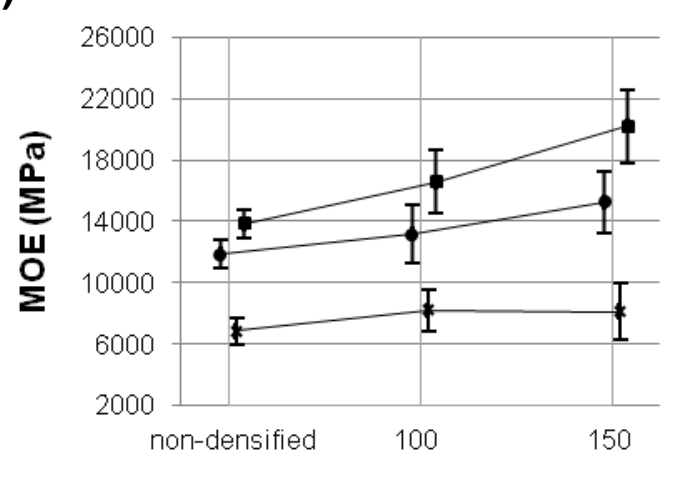

Temperature $\left({ }^{\circ} \mathrm{C}\right)$

d)

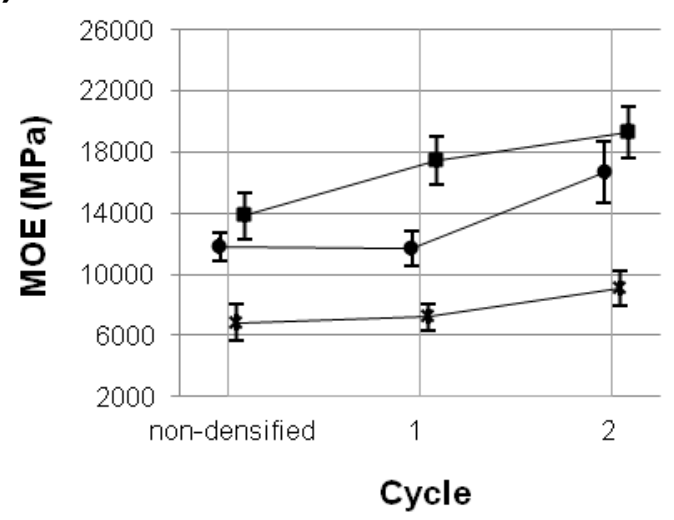

Fig. 3. MOR ( $a, c)$ and MOE (b, d) of thermo-mechanically modified wood species

The greatest changes in the MOR values that were dependent on the number of thermo-mechanical modification cycles were noted in iroko wood (Fig. 3c). The MOR of iroko wood after one treatment cycle increased 45\%; after two cycles it was twice as high as before the modification. This meant a 36\% difference between its MOR after one and after two treatment cycles. The MOR of tauari wood after one and two treatment cycles increased $78 \%$ and $90 \%$ from its baseline, respectively. The MOR of oak wood after one treatment cycle was higher $51 \%$, and after two cycles $77 \%$ in comparison to its value before the modification. Ülker et al. (2012), after densifying pine (Pinus sylvestris L.) wood at $120{ }^{\circ} \mathrm{C}$, noted an increase in density of $83 \%$ and that the highest increase in bending strength was $42 \%$ (an increase from $69.13 \mathrm{~N} / \mathrm{mm}^{2}$ to $98.55 \mathrm{~N} / \mathrm{mm}^{2}$ ). The MOE of pine wood modified at $120{ }^{\circ} \mathrm{C}$ increased $11 \%$. The authors stated that the most suitable temperature level was $120^{\circ} \mathrm{C}$ for a higher MOR.

As a result of higher modification temperature, the change in the MOE was greater in tauari wood than in oak or iroko wood (Fig. 3b). The MOE of tauari wood modified at $100{ }^{\circ} \mathrm{C}$ and $150{ }^{\circ} \mathrm{C}$ increased $20 \%$ and $46 \%$, respectively, with regard to the wood's MOE 
before the densification. Smaller differences were noted in oak wood. The MOE of oak wood modified at $100{ }^{\circ} \mathrm{C}$ and $150{ }^{\circ} \mathrm{C}$ was, respectively, $11 \%$ and $29 \%$ greater than before the densification. The MOE of iroko wood densified at $100{ }^{\circ} \mathrm{C}$ and $150{ }^{\circ} \mathrm{C}$ was at a similar level (MOE increased ca. 20\%).

Performing the second thermo-mechanical modification cycle resulted in a considerable improvement in the MOE of the tested wood species (Fig. 3d). The MOE values of non-densified oak and tauari wood (Table 4) were close to literature data. According to literature, the MOE of oak wood amounts to $10000 \mathrm{MPa}$ to $13200 \mathrm{MPa}$, and the MOE of tauari wood is $14500 \mathrm{MPa}$ (Wagenführ 2007; CIRAD 2012). The MOE of the tested iroko wood was lower than $9400 \mathrm{MPa}$ to $13000 \mathrm{MPa}$, which is the range established by previous studies (Wagenführ 2007). This resulted from its irregular fibres arrangement, a typical defect of iroko wood, which significantly contributed to the lower MOE values. After one modification cycle, the MOE of oak and iroko wood were nearly identical to the MOE of non-densified wood. However, after two thermo-mechanical modification cycles, the MOE of oak and iroko wood exceeded the MOE of non-densified oak and iroko wood $41 \%$ and $32 \%$, respectively. The MOE of tauari wood after one modification cycle was $26 \%$ higher, and after two modification cycles it was $40 \%$ higher than the MOE measured prior to densification (Fig. 3d).

Table 3. Mean Values of the Tested Parameters

\begin{tabular}{|c|c|c|c|c|c|c|}
\hline $\begin{array}{c}\text { Wood } \\
\text { Species/Variant }\end{array}$ & $\begin{array}{c}\text { Temperature } \\
\left({ }^{\circ} \mathrm{C}\right)\end{array}$ & Cycle & $\begin{array}{c}\text { Thickness } \\
(\mathrm{mm})\end{array}$ & $\begin{array}{c}\text { Density } \\
\left(\mathrm{kg} / \mathrm{m}^{3}\right)\end{array}$ & $\begin{array}{c}\text { MOR } \\
(\mathrm{MPa})\end{array}$ & $\begin{array}{c}\text { MOE } \\
(\mathrm{MPa})\end{array}$ \\
\hline Oak Non-densified & - & - & $8.67(0.35)$ & $651(35)$ & $123(22)$ & $11850(920)$ \\
\hline \multirow{2}{*}{ Oak Densified } & 100 & 1 & $5.93(0.09)$ & $1015(18)$ & $168(10)$ & $11410(480)$ \\
\cline { 2 - 7 } & 150 & 2 & $5.05(0.08)$ & $1079(32)$ & $206(10)$ & $14890(580)$ \\
\cline { 2 - 7 } & & 2 & $5.36(0.20)$ & $1028(27)$ & $205(21)$ & $11980(960)$ \\
\hline Iroko Non-densified & - & - & $8.69(0.32)$ & $564(29)$ & $74(26)$ & $6840(900)$ \\
\hline Iroko Densified & 100 & 1 & $5.72(0.07)$ & $769(15)$ & $108(12)$ & $7030(860)$ \\
\cline { 2 - 7 } & & 2 & $5.59(0.14)$ & $784(6)$ & $148(15)$ & $9340(320)$ \\
\cline { 2 - 7 } & 150 & 1 & $5.92(0.11)$ & $732(33)$ & $121(14)$ & $7400(860)$ \\
\cline { 2 - 7 } & & 2 & $5.83(0.43)$ & $758(49)$ & $132(12)$ & $8760(670)$ \\
\hline Tauari Non-densified & - & - & $8.62(0.43)$ & $694(41)$ & $155(28)$ & $13830(920)$ \\
\hline Tauari Densified & 100 & 1 & $6.01(0.10)$ & $974(26)$ & $238(24)$ & $15000(950)$ \\
\cline { 2 - 6 } & & 2 & $5.60(0.21)$ & $1071(39)$ & $274(18)$ & $18140(1280)$ \\
\cline { 2 - 7 } & 150 & 1 & $5.57(0.19)$ & $1098(27)$ & $314(23)$ & $19920(1270)$ \\
\cline { 2 - 7 } & & 2 & $5.17(0.26)$ & $1138(44)$ & $316(29)$ & $20490(2900)$ \\
\hline
\end{tabular}

Values in parenthesis are standard deviation

Detailed data on the tested wood properties (for each variant of CTMT) are presented in Table 4. The smallest thickness $(4.96 \mathrm{~mm} \pm 0.09 \mathrm{~mm})$ was observed in oak wood after two modification cycles, densified at a temperature of $150{ }^{\circ} \mathrm{C}$. The oak wood densified in these conditions was characterized by a $\mathrm{ca}$. $43 \%$ compression ratio and a $70 \%$ increase in density over non-densified oak wood, which was the greatest change in density. The highest density $\left(1138 \mathrm{~kg} / \mathrm{m}^{3} \pm 44 \mathrm{~kg} / \mathrm{m}^{3}\right)$ was noted for tauari wood after two modification cycles, densified at $150{ }^{\circ} \mathrm{C}$. The tauari wood modified in this manner had the greatest MOR $(316 \mathrm{MPa} \pm 29 \mathrm{MPa})$ and MOE $(20490 \mathrm{MPa} \pm 2900 \mathrm{MPa})$. The thermomechanical modification performed in two cycles doubled the MOR of iroko wood, which was the greatest increase in MOR. This was regarding the iroko wood modified at temperatures $100{ }^{\circ} \mathrm{C}$ and $150{ }^{\circ} \mathrm{C}$. The second treatment cycle neutralized the negative 
impact of the irregular fibres on the properties of thermo-mechanically modified iroko wood. A similar increase in the MOR value was observed in the tauari wood modified at $150{ }^{\circ} \mathrm{C}$. The biggest differences in the MOE after densification were noted in oak wood. The MOE of oak wood densified at $150{ }^{\circ} \mathrm{C}$ after two modification cycles was $56 \%$ greater than the MOE of non-densified oak wood.

\section{CONCLUSIONS}

1. The thermo-mechanical modification had significant impact on the thickness, density, MOR, and MOE of oak, iroko, and tauari wood.

2. The impact of modification temperature was greatest on the properties of densified tauari wood and smallest on the properties of densified iroko wood.

3. The second cycle of thermo-mechanical modification had a significant impact on the MOR and MOE of oak, iroko, and tauari wood densified at $100{ }^{\circ} \mathrm{C}$ and the MOE of oak and iroko wood densified at $150{ }^{\circ} \mathrm{C}$.

4. A negative impact of high modification temperature, at $150{ }^{\circ} \mathrm{C}$, on iroko wood was demonstrated. It was manifested in the lower compression ratio of iroko wood at 150 ${ }^{\circ} \mathrm{C}$ than at $100{ }^{\circ} \mathrm{C}$.

5. The thermo-mechanical modification performed over two cycles doubled the MOR of iroko wood (densified at $100{ }^{\circ} \mathrm{C}$ or $150{ }^{\circ} \mathrm{C}$ ) and led to the highest increase, by about $56 \%$, in MOE in oak wood (densified at $150{ }^{\circ} \mathrm{C}$ ).

\section{ACKNOWLEDGMENTS}

The author thank The Institute of Wood Sciences and Furniture, Warsaw University of Life Sciences for their financial support.

\section{REFERENCES CITED}

Bekhta, P., Proszyk, S., and Krystofiak, T. (2014a). "Colour in short term thermomechanically densified veneer of various wood species," Eur. J. Wood Wood Prod. 72(6), 785-797. DOI: 10.1007/s00107-014-0837-1

Bekhta, P., Proszyk, S., Lis, B., and Krystofiak, T. (2014b). "Gloss of thermally densified alder (Alnus glutinosa Goertn.), beech (Fagus sylvatica L.), birch (Betula verrucosa Ehrh.), and pine (Pinus sylvestris L.) wood veneers," Eur. J. Wood Wood Prod. 72(6), 799-808. DOI: 10.1007/s00107-014-0843-3

Blomberg, J., Persson, B., and Blomberg, A. (2005). "Effects of semi-isostatic densification of wood on the variation in strength properties with density," Wood Sci. Technol. 39(5), 339-350. DOI: 10.1007/s00226-005-0290-8

Candan, Z., Hiziroglu, S., and McDonald, A. G. (2010). "Surface quality of thermally compressed Douglas fir veneer," Mater. Des. 31(7), 3574-3577. DOI: 10.1016/j.matdes.2010.02.003 
CIRAD (2012). "Tauari. Tropix 7. Agricultural research for development," (https://tropix.cirad.fr/), Accessed 20 Nov 2019.

Dilik, T., and Hiziroglu, S. (2012). "Bonding strength of heat treated compressed Eastern redcedar wood," Mater. Des. 42, 317-320. DOI: 10.1016/j.matdes.2012.05.050

EN 13556 (2003). "Round and sawn timber. Nomenclature of timbers used in Europe," European Committee for Standardization, Brussels, Belgium.

Fang, C.-H., Mariotti, N., Cloutier, A., Koubaa, A., and Blanchet, P. (2012). "Densification of wood veneers by compression combined with heat and steam," Eur. J. Wood Wood Prod. 70(1-3), 155-163. DOI: 10.1007/s00107-011-0524-4

$\mathrm{Fu}$, Q., Cloutier, A., and Laghdir, A. (2016). "Optimization of the thermohygromechanical (THM) process for sugar maple wood densification," BioResources 11(4), 8844-8859. DOI: 10.15376/biores.11.4.8844-8859

Gaff, M., and Gašparík, M. (2015). "Influence of densification on bending strength of laminated beech wood," BioResources 10(1), 1506-1518. DOI: 10.15376/biores.10.1.1506-1518

Gašparík, M., Gaff, M., Šafaříková, L., Vallejo, C. R., and Svoboda, T. (2016). "Impact bending strength and Brinell hardness of densified hardwoods," BioResources 11(4), 8638-8652. DOI: 10.15376/biores.11.4.8638-8652

ISO 3129 (2012). "Wood - Sampling methods and general requirements for physical and mechanical testing of small clear wood specimens," International Organization for Standardization, Geneva, Switzerland.

ISO 13061-1 (2014). "Physical and mechanical properties of wood - Test methods for small clear wood specimens - Part 1: Determination of moisture content for physical and mechanical tests," International Organization for Standardization, Geneva, Switzerland.

ISO 13061-2 (2014). "Physical and mechanical properties of wood - Test methods for small clear wood specimens - Part 2: Determination of density for physical and mechanical tests," International Organization for Standardization, Geneva, Switzerland.

ISO 13061-3 (2014). "Physical and mechanical properties of wood - Test methods for small clear wood specimens - Part 3: Determination of ultimate strength in static bending," International Organization for Standardization, Geneva, Switzerland.

ISO 13061-4 (2014). "Physical and mechanical properties of wood - Test methods for small clear wood specimens - Part 4: Determination of modulus of elasticity in static bending," International Organization for Standardization, Geneva, Switzerland.

İmirzi, H. Ö., Ülker, O., and Burdurlu, R. (2014). "Effect of densification temperature and some surfacing techniques on the surface roughness of densified scots pine (Pinus sylvestris L.)," BioResources 9(1), 191-209. DOI: 10.15376/biores.9.1.191209

Kretschmann, D. E. (2010). Mechanical Properties of Wood. Chapter 5 (General Technical Report FPL-GTR-190), U.S. Department of Agriculture Forest Products Laboratory, Madison, WI, USA.

Kurowska, A., Borysiuk, P., Mamiński, M., and Zbieć, M. (2010). "Veneer densification as a tool for shortening of plywood pressing time," Drvna Industrija 61(3), 193-196.

Kutnar, A., and Šernek, M. (2007). "Densification of wood," Zbornik Gozdarstva in Lesarstva 82, 53-62. 
Kutnar, A., Kamke, F. A., and Sernek, M. (2009). "Density profile and morphology of viscoelastic thermal compressed wood," Wood Sci. Technol. 43(1), 57-68. DOI: 10.1007/s00226-008-0198-1

Kutnar, A., and Kamke, F. A. (2012). "Influence of temperature and steam environment on set recovery of compressive deformation of wood," Wood Sci. Technol. 46(5), 953-964. DOI: 10.1007/s00226-011-0456-5

Laine, K., Rautkari, L., Hughes, M., and Kutnar, A. (2013). "Reducing the set-recovery of surface densified solid Scots pine wood by hydrothermal post-treatment," Eur. J. Wood Wood Prod. 71(1), 17-23. DOI: 10.1007/s00107-012-0647-2

Laine, K., Segerholm, K., Wålinder, M., Rautkari, L., and Hughes, M. (2016). "Wood densification and thermal modification: Hardness, set-recovery and micromorphology," Wood Sci. Technol. 50(5), 883-894. DOI: 10.1007/s00226-016-0835-z

Laskowska, A. (2017). "The influence of process parameters on the density profile and hardness of surface-densified birch wood (Betula pendula Roth)," BioResources 12(3), 6011-6023. DOI: 10.15376/biores.12.3.6011-6023

Laskowska, A., Marchwicka, M., Boruszewski, P., and Wyszyńska, J. (2018). "Chemical composition and selected physical properties of oak wood (Quercus robur L.) modified by cyclic thermo-mechanical treatment," BioResources 13(4), 9005 - 9019. DOI: 10.15376/biores.13.4.9005-9019

Popescu, M.-C., Lisa, G., Froidevaux, J., Navi, P., and Popescu, C.-M. (2014). "Evaluation of the thermal stability and set recovery of thermo-hydro-mechanically treated lime (Tilia cordata) wood," Wood Sci. Technol. 48(1), 85-97. DOI: 10.1007/s00226-013-0588-x

Rautkari, L., Properzi, M., Pichelin, F., and Hughes, M. (2010). "Properties and setrecovery of surface densified Norway spruce and European beech," Wood Sci. Technol. 44(4), 679-691. DOI: 10.1007/s00226-009-0291-0

Rautkari, L., Laine, K., Laflin N., and Hughes, M. (2011). "Surface modification of Scots pine: The effect of process parameters on the through thickness density profile," $J$. Mater. Sci. 46(14), 4780-4786. DOI: 10.1007/s10853-011-5388-9

Rautkari, L., Laine, K., Kutnar, A., Medved, S., and Hughes, M. (2013). "Hardness and density profile of surface densified and thermally modified Scots pine in relation to degree of densification," J. Mater. Sci. 48(6), 2370-2375. DOI: 10.1007/s10853-0127019-5

Richter, H. G., and Dallwitz, M. J. (2000). "Commercial timbers: Descriptions, illustrations, identification, and information retrieval," (http://delta-intkey.com), Accessed 15 Nov 2019.

Tu, D., Su, X., Zhang, T., Fan, W., and Zhou, Q. (2014). "Thermo-mechanical densification of Populus tomentosa var. tomentosa with low moisture content," BioResources 9(3), 3846-3856. DOI: 10.15376/biores.9.3.3846-3856

Ülker, O., İmirzi, Ö., and Burdurlu, E. (2012). "The effect of densification temperature on some physical and mechanical properties of Scots pine (Pinus sylvestris L.)," BioResources 7(4), 5581-5592. DOI: 10.15376/biores.7.4.5581-5592

Ülker, O., and Hiziroglu, S. (2017). "Some properties of densified eastern redcedar as function of heat and pressure," Materials 10(11), Article Number 1275. DOI: 10.3390/ma10111275

Wagenführ, R. (2007). Holzatlas [The Atlas of Wood], Fachbuchverlag Leipzig, München, Germany. 
Zhan, J.-F., and Avramidis, S. (2016). "Needle fir wood modified by surface densification and thermal post-treatment: Hygroscopicity and swelling behavior," Eur. J. Wood Wood Prod. 74(1), 49-56. DOI: 10.1007/s00107-015-0969-y

Article submitted: December 2, 2019; Peer review completed: February 1, 2020; Revised version received and accepted; February 12, 2020; Published: March 9, 2020.

DOI: $10.15376 /$ biores. 15.2.2869-2881 